\title{
OPTIMALISASI NURSING HANDOVER DI RUMAH SAKIT SWASTA BANJARMASIN
}

\author{
Dewi Setya Paramitha ${ }^{1 *}$, Noor Amaliah², Herman Ariadi ${ }^{3}$ \\ ${ }^{1-3}$ Universitas Muhammadiyah Banjarmasin \\ Email Korespondensi: dsp@umbjm.ac.id
}

\begin{abstract}
ABSTRAK
Penyebaran Covid-19 menjadikan permasalahan serius yang berdampak pada perubahan sistem pelayanan di rumah sakit. Menjadi tantangan bagi perawat jika selalu melaksanakan handover di samping tempat tidur pasien karena berisiko tinggi terpapar Covid-19. Tujuan program adalah optimalisasi nursing handover masa pandemi untuk tetap menjamin efektifitas kesinambungan perawatan tanpa mengesampingkan prinsip patient safety. Program ini dirancang dengan mengadakan workshop untuk perawat dan pendampingan pelaksanaan di rawat inap percontohan di rumah sakit swasata Banjarmasin. Bedside handover di kamar pasien saat pandemi dilakukan kurang dari 2 menit demi menjaga kepuasan pasien namun tetap meminimalkan waktu kontak dengan pasien. Formulir handover tidak hanya diterapkan untuk ruang rawat inap, tetapi juga untuk ruang-ruangan lain yang berkaitan dengan tindakan pasien. Pentingnya pelaksanaan dan dokumentasi nursing handover adalah untuk menjamin aspek legal etik asuhan keperawatan. Saran yang diharapkan adalah peningkatan kegiatan supervisi keperawatan untuk menjamin pelaksanaan nursing handover tetap sesuai dengan standar yang ditetapkan. Rumah sakit disarankan mengembangkan dokumentasi asuhan keperawatan digital guna menyikapi tantangan new normal.
\end{abstract}

Kata Kunci: Nursing handover, Pandemi Covid-19, Program pendampingan, Ruang rawat, Workshop

\begin{abstract}
The spread of Covid-19 is a serious problem that has an impact on changing the healthcare system. It is a challenge for nurses because of the high risk of exposure to Covid-19. This program was to optimize nursing handover during the pandemic to ensure the continuity of care without compromising the patient safety. This program was designed by workshop and mentoring one of pilot ward at Banjarmasin privat hospital. Bedside handovers inpatient wards during pandemic were carried out for less than 2 minutes to maintain patient satisfaction while minimizing contact duration with patients. The handover form was not only applied to inpatient wards, but also to other wards related to medical procedure. The importance of implementing and documenting nursing handovers is to ensure the legal and ethical aspects of nursing care. Nurse manager suggested to increase nursing supervision to ensure nursing handover runs accordance with standard. Hospital should to develop digital nursing care documentation to face the challenges of the new normal.
\end{abstract}

Keywords: Covid-19 Pandemic, Hospital ward, Nursing handover, Mentoring program, Workshop 


\section{PENDAHULUAN}

Nursing handover atau timbang terima merupakan komunikasi yang memiliki tujuan untuk mengakurasi, mereliabilisasi tentang tugas perpindahan informasi dari perawat jaga sebelumnya ke perawat jaga yang akan datang. Nursing handover yang efektif akan menjaga kesinambungan dalam keselamatan pasien dan kulitas asuhan keperawatan (Loefgren Vretare and Anderzén-Carlsson, 2020).

Sebagian besar waktu dan pekerjaan perawat melibatkan kontak langsung dengan pasien sehingga perawat memiliki kerentanan yang tinggi terhadap virus Covid-19 (Utama, Sukmawati and Dianty, 2020). Perlu dibuat protokol khusus rumah sakit untuk mengurangi risiko infeksi perawat dalam interaksi dengan pasien Covid-19 (Huang et al., 2020). Perawat sebagai garda terdepan melawan Covid-19 perlu memiliki penguatan sistem pemberian perawatan kesehatan untuk tetap menjaga keselamatan pasien (Al Thobaity and Alshammari, 2020).

Pandemi Covid-19 telah menimbulkan tantangan baru dalam nursing handover. Nursing handover dilakukan dengan minimal peserta, perawat yang terlibat di samping tempat tidur hanya yang saat itu bertugas. Sedangkan perawat lainnya berada di ruang rapat yang berbeda atau bahkan di kantor masing-masing (Wasserteil et al., 2020). Semua dokumen medis dan bahan perawatan disarankan tidak mengandung kertas (Huang et al., 2020).

Nursing handover adalah suatu cara dalam menyampaikan dan menerima laporan perawatan yang berkaitan dengan keadaan klien. Nursing handover merupakan kegiatan yang harus dilakukan sebelum perawat melakukan pergantian dinas. Selain laporan antar shift, dapat disampaikan juga informasi yang berkaitan dengan rencana kegiatan yang telah atau belum diimplementasikan (Nursalam, 2015).

Nursing handover yang efektif dilaksanakan dengan menggunakan prinsip SBAR (Situation, Background, Assessment and Recommendation) (Oxyandi and Endayni, 2020). Komponen tersebut meliputi Situation yaitu menyebut usia klien, jenis kelamin, diagnosis pre operasi, prosedur, status mental, kondisi klien apakah stabil atau tidak. Background menampilkan pokok masalah atau apa saja yang terjadi pada diri klien, keluhan yang mendorong untuk dilaporkan seperti sesak nafas, nyeri dada, dan sebagainya. Menyebutkan latar belakang apa yang menyebabkan munculnya keluhan klien tersebut, diagnosis klien, dan data klinik yang mendukung masalah klien. Assesment berisi hasil pemikiran yang timbul dari temuan serta difokuskan pada problem yang terjadi pada klien yang apabila tidak diantisipasi akan menyebabkan kondisi yang lebih buruk. Recommendation menyebutkan halhal yang dibutuhkan untuk ditindak lanjuti (Standar Nasional Akreditasi Rumah Sakit Edisi 1.1, 2019).

Nursing handover dengan metode SBAR yang efektif adalah dilakukan di samping tempat tidur pasien (bedside handover). Kegiatannya melibatkan pasien secara aktif selama interaksi antara perawat dengan pasien pada setiap pergantian shift. Pasien diperbolehkan untuk bertanya apa saja yang mereka ingin tahu tentang kondisi kesehatannya, komplain serta meminta perawatan kepada perawat (Rifai, Afandi and Hasanah, 2020).

Pembinaan (coaching) komunikasi SBAR efektif diaksanakan pada nursing handover. Terdapat peningkatan yang signifikan pada kapabilitas kepala ruangan dan nursing handover setelah diberikan intervensi coaching (Herawati et al., 2018). 
Komite Penanganan Covid-19 dan Pemulihan Ekonomi Nasional Indonesia menyebutkan pada Januari 2020 jumlah kasus terkonfirmasi Covid-19 di Indonesia sudah lebih dari 836.000 kasus dan yang terkonfirmasi meninggal lebih dari 24.000 kasus. Berdasarkan data Gugus Tugas Percepatan Penanganan Covid-19 di Kalimantan Selatan tercatat lebih dari 16.000 kasus terkonfirmasi dan kasus meninggal sejumlah 600 .

Sejumlah korban meninggal akibat Covid-19 juga dialami oleh tenaga kesehatan. Informasi dari Persatuan Perawat Nasional Indonesia 75\% perawat yang meninggal akibat Covid-19 umumnya justru bertugas di kamar rawat inap biasa bukan di ruang khusus perawatan Covid-19. Bahkan beberapa waktu lalu terdapat satu perawat rumah sakit swasta di Banjarmasin yang meninggal akibat terinveksi Covid-19 (Haswar, 2020). Rumah sakit mitra pengabdian merupakan salah satu rumah sakit swasta tipe $\mathrm{C}$ di Kalimantan Selatan. Saat ini rumah sakit memiliki ruangan khusus perawatan Covid-19. Pelaksanaan nursing handover di rumah sakit masih dilaksankan di nurse station dan di samping tempat tidur pasien. Kondisi seperti ini memungkinkan risiko tinggi terjadi penularan virus Covid-19 jika dilakukan secara terus menerus di masa pandemi ini.

\section{MASALAH}

Walaupun kebanyakan pasien yang ditangani di ruang rawat inap adalah pasien-pasien dengan kasus reguler namun kegiatan bedside nursing handover tetap saja menjadi sumber penularan Covid-19. Hal ini dikarenakan adanya pasien yang terinfeksi Covid-19 namun tidak menimbulkan gejala, atau adanya penularan dari keluarga pasien yang berkunjung. Penting bagi rumah sakit untuk memodifikasi pelaksanaan nursing handover di kondisi sekarang sehingga tidak ada lagi perawat yang menjadi korban.

Oleh karena itu, sebagai bentuk dukungan sesama anggota amal usaha Muhammadiyah maka untuk menyelesaikan permasalahan ini diberikan solusi berupa program optimalisasi nursing handover di masa pandemi. Bentuk kegiatan yang dilakukan adalah workshop nursing handover masa pandemi beserta pendampingan pelaksanaannya. Luaran yang dihasilkan berupa modifikasi pelaksanaan handover dan formulir handover yang dapat digunakan di beberapa ruangan di rumah sakit. Solusi ini dirasa bermanfaat untuk menjamin mutu pelayanan.

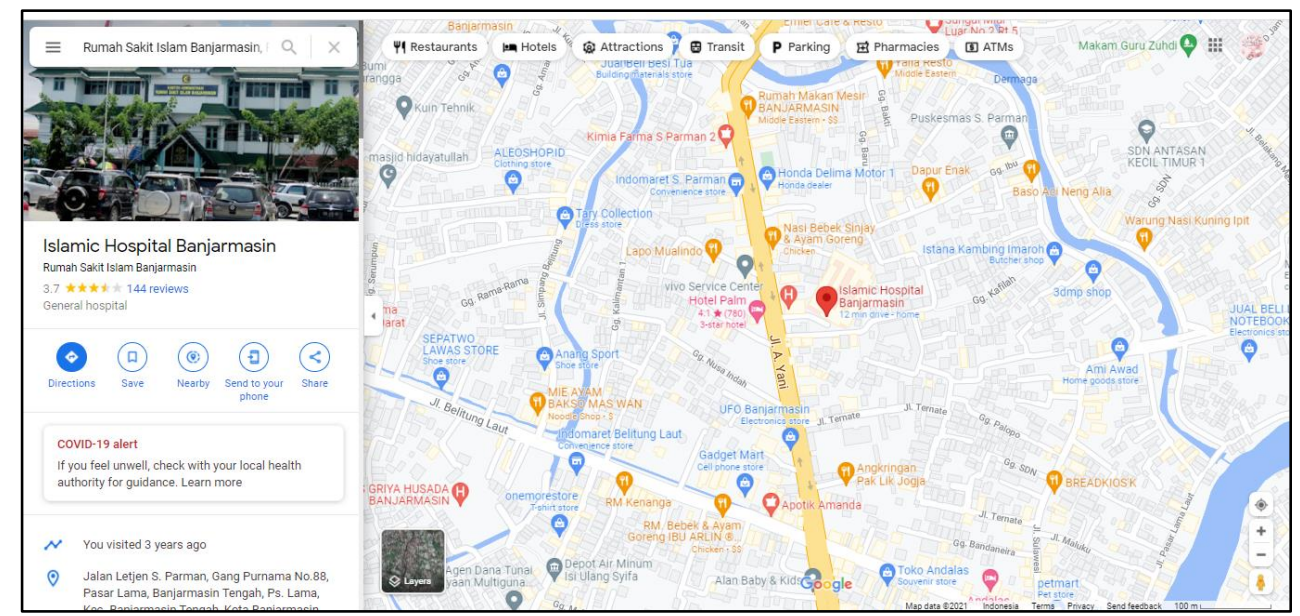

Gambar 1. Peta lokasi Rumah Sakit Islam Banjarmasin 


\section{METODE}

Metode yang digunakan dengan cara melakukan workshop dan pendampingan pelaksanaan di ruang percontohan. Kegiatan ini memiliki tujuan umum yaitu perawat di rumah sakit mampu mengoptimalkan pelaksanaan nursing handover di masa pandemi. Tujuan khusus yaitu perawat mampu memahami konsep nursing handover, mampu modifikasi pelaksanaan handover, mampu menyusun formulir nursing handover dan mampu menerapkan SPO nursing handover.

Pengabdian masyarakat dilaksanakan pada bulan Mei s.d Juli 2021. Pengabdian masyarakat di salah satu rumah sakit swasta di Banjarmasin. Sasaran program adalah perawat ruangan dan perawat manajer di rumah sakit.

Adapun kegiatan dilakukan dengan beberapa tahapan, yaitu:

a. Focus Group Discussion (FGD)

Melakasanakan FGD dengan perawat dan tim manajerial keperawatan di rumah sakit. Memperoleh data hasil diskusi perawat di rumah sakit tentang pelaksanaan nursing handover yang selama ini dilakukan. Menggali sumber daya yang mendukung modifikasi pelaksanaan nursing handover masa pandemi

b. Pre test

Mengidentifikasi pengetahuan perawat tentang nursing handover sebelum materi diberikan

c. Workshop

Meningkatkan wawasan perawat, merevisi SPO nursing handover jika diperlukan, menyusun formulir handover, mendemonstrasikan nursing handover

d. Post test

Mengidentifikasi pengetahuan perawat tentang nursing handover seletah workshop

e. Pendampingan

Pendampingan dan observasi langsung pelaksanaan nursing handover di ruang percontohan.

f. Evaluasi

Mengidentifikasi efektifktas pelaksanaan nursing handover.

\section{HASIL DAN PEMBAHASAN}

\section{a. Focus Group Discussion (FGD)}

Focus Group Discussion dimaksudkan untuk memperoleh secara mendalam kebutuhan spesifik mitra. Wawancara mendalam ini untuk membahas rencana kegiatan beserta kemungkinan yang ada dan mampu dilaksanakan secara maksimal sesuai sumber daya yang dimiliki oleh rumah sakit.

Pelaksanaan FGD dihadiri oleh Kasie. Keperawatan dan Kebidanan, perwakilan kepala ruangan dan perwakilan ketua tim untuk memperoleh data hasil diskusi perawat di rumah sakit tentang pelaksanaan nursing handover yang selama ini dilakukan. Diperoleh data bahwa selama ini masih menggunakan SPO yang lama namun hanya menyesuaikan dengan waktu bedside handover yang lebih singkat dari pada biasanya. Hal ini dikarenakan untuk meminimalisir kontak dengan pasien saat pandemi Covid-19. Pada kesempatan kali itu juga disepakati tentang tanggal pelaksanaan workshop dan daftar peserta yang akan diikutsertakan. 


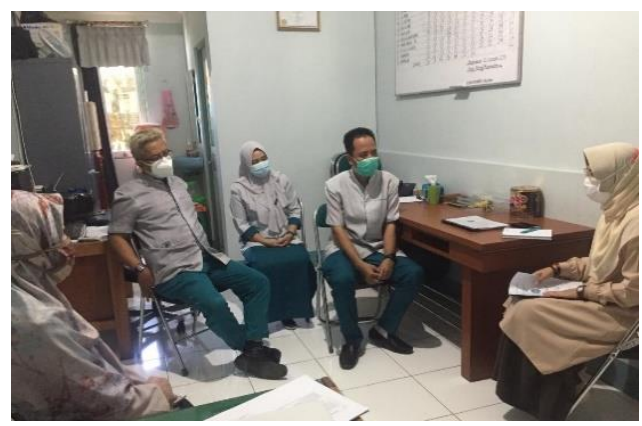

Gambar 1. Focus Group Discussion dengan Perwakilan Perawat

b. Pre test

Pre test dilaksanakan sebelum pelaksanaan workshop. Pretest akan membantu mengetahui kemampuan awal para peserta workshop sebelum materi disampaikan. Hasil pretest akan memudahkan narasumber untuk memberi penekanan pada materi yang akan disampaikan. Pretest dilakukan pada 26 peserta. Berdasarkan hasil pre test dapat dilihat bahwa sebagian besar peserta memiliki pengetahuan cukup, namun masih ada 4 orang yang memiliki pengetahuan kurang dan hanya terdapat 2 orang yang memiliki pengetahuan tinggi.

Tabel 1. Pretest Pengetahun Peserta tentang Handover

\begin{tabular}{ccc}
\hline No & Kategori Pengetahuan & Jumlah \\
\hline 1 & Kurang & 4 \\
\hline 2 & Cukup & 20 \\
\hline 3 & Tinggi & 2 \\
\hline & Jumlah & 26 \\
\hline
\end{tabular}

\section{c. Workshop}

Pelaksanaan workshop tidak dilaksanakan secara daring karena beberapa alasan yaitu kurangnya interaksi antara narasumber dengan peserta atau diantara para peserta itu sendiri, ada kecenderungan mengabaikan materi yang disampaikan, motivasi cenderung rendah (Fatwa, 2020). Oleh karena itu pelaksanaan workshop disepakati dilakukan secara luring di bertempat di aula rumah sakit dengan pertimbangan bahwa untuk memaksimalkan pemahaman para perawat, adaya interaksi saat role play dan mudahkan pengevaluasian.

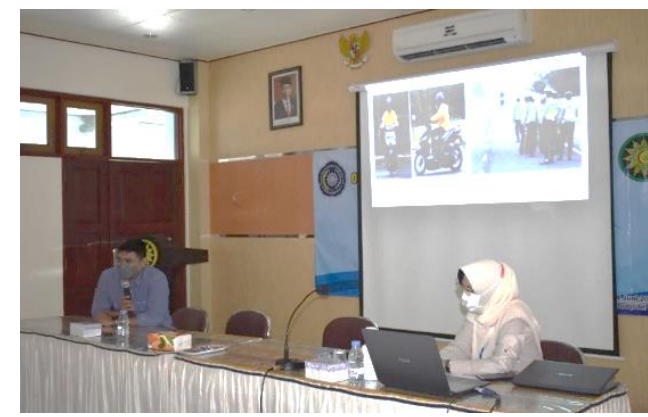

Gambar 2. Pemberian Materi oleh Narasumber Workshop

Pelaksanaan workshop tetap menaati protokol kesehatan. Kegiatan diawali dengan pretest untuk menggali pemahaman perawat tentang 
handover. Peserta yang hadir sejumlah 26 orang, meliputi Kabid. Keperawatan dan Kebidanan, Kasie. Keperawatan dan Kebidanan, Ketua Komite Keperawatan, Case Manager, Ka. Unit Diklat, para kepala ruangan, kepala unit ruang perawatan dan ketua tim, perawat primer dan tim akreditasi rumah sakit.

Materi yang disampaikan oleh narasumber tentang kebijakan akreditasi versi SNARS 1.1 tentang handover dan konsep pelaksanaan handover. Setelah selesai materi dari narasumber acara dilanjutkan dengan diskusi. Para peserta antusias dengan materi yang disampaikan. Banyak pertanyaan yang diajukan oleh peserta kepada narasumber. Selain pertanyaan tentang teknis pelaksanaan handover di ruang rawat inap biasa, peserta juga menanyakan tentang teknis pelaksanaan handover di ruang operasi, ruang hemodialisa, unit gawat darurat dan ruang pemeriksaan penunjang (rongent, laboratorium, dll).

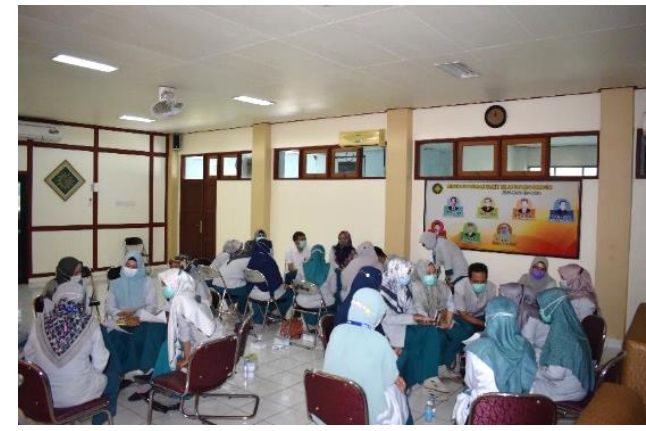

Gambar 3. Diskusi dan Pendampingan Review SPO dan Formulir Handover

Setelah diskusi kegiatan dilanjutkan dengan pendampingan review SPO handover dan formulir yang telah ada. Kegiatan penyusunan dibagi atas beberapa kelompok. Terdapat tiga kelompok diskusi yaitu kelompok 1 (Ruang Operasi dan IGD), kelompok 2 (Ruang Hemodialisa dan ICU), dan kelompok 3 (Ruang Rawat Inap). Berdasarkan hasil diskusi ternyata terdapat ruangan yang belum memiliki formulir handover. Oleh karena itu, pada saat pendampingan juga mencoba dirumumuskan SPO baru dan formulir handover untuk tindakan sementara (operasi, pemeriksaan penunjang, dll) di luar ruang rawat inap. Kegiatan selajutnya adalah role play pelaksanaan handover sesuai dengan pembagian ruangan yang telah ditentukan.

Pada saat pelaksanaan role play semua kelompok diskusi mempraktikan cara berkomunikasi yang benar sesuai dengan prosedur handover. Komunikasi saat handover yang diajarkan berdasarkan dengan SBAR, hal ini dimaksudkan untuk memberikan informasi yang efektif dan meningkatkan keselamatan pasien. Para perawat terlihat mendemontrasikan handover dengan cukup baik. Selesai role play oleh semua kelompok, narasumber memberikan feedback terhadap apa yang sudah didemonstrasikan. Adapun beberapa feedback dari narasumber adalah saat handover harus ada validasi dari perawat yang menerima informasi, critical point disampaikan harus yang berkaitan dengan masalah pasien, penyampaian masalah keperawatan dan tindakan mandiri keperawatan sering terlupakan sehingga harus ditekankan kembali. 


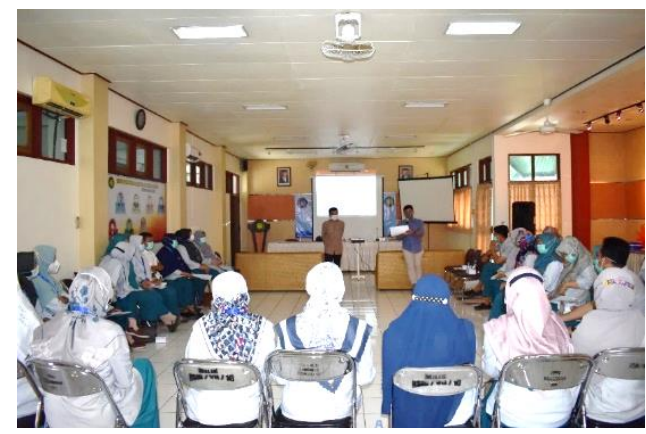

Gambar 4. Role Play Handover dan Feedback dari Narasumber

Pada akhir acara workshop kegiatan diisi dengan penyusunan rencana tindak lanjut. Adapun rencana tindak lanjut yang disepakati adalah merevisi formulir handover dari formulir yang sudah ada dan contoh, mensosialisasi formulir baru ke ruangan, pelaksanaan pendampingan handover pada ruang percontohan selama 4 minggu.

\section{d. Post test}

Pada akhir workshop ditutup dengan post test untuk mengevaluasi pemahaman peserta. Seperti halnya pretest, soal yang digunakan pada saat post test adalah soal yang sebelumnya diberikan pada saat pretest. Dengan demikian, hasil antara nilai pretest dan nilai post test dapat menjadi bahan perbandiangan dan evaluasi pemahaman para peserta workshop.

Berdasarkan hasil post test dapat dilihat terjadi peningkatan pengetahuan peserta tentang handover. Walaupun sebagian besar peserta memiliki pengetahuan cukup, namun setelah diberikan materi peserta yang memiliki pengetahuan kurang menjadi hanya 1 orang dan yang pengetahuan tinggi meningkat menjadi 7 orang. Kondisi ini menunjukan bahwa pemberian materi memberikan dampak pada peningkatan pengetahuan peserta.

Tabel 2. Post test Pengetahun Peserta tentang Handover

\begin{tabular}{ccc}
\hline No & Kategori Pengetahuan & Jumlah \\
\hline 1 & Kurang & 1 \\
\hline 2 & Cukup & 18 \\
\hline 3 & Tinggi & 7 \\
\hline & Jumlah & 26 \\
\hline
\end{tabular}

\section{e. Pendampingan}

Sesuai dengan rencana tindak lanjut yang telah disepakati, adapun kegiatan pendampingan yaitu:

SPO dan formulir-formulir yang berkaitan ditinjau kembali, kemudian diperbaiki oleh tim manajerial keperawatan rumah sakit dan dirapatkan untuk ditetapkan. Setelah itu disosialisasikan ke ruangan-ruangan untuk mendapatkan pemahaman yang menyeluruh ke perawat-perawat di rumah sakit.

Proses handover tetap dilakukan oleh perawat antarshift di ruang nurse station. Handover di rumah sakit disepakati tidak dilaksanakan menggunakan media digital (daring). Para perawat menyepakati bahwa 
komunikasi secara langsung akan lebih efektif. Handover di nurse station dilakukan dengan metode SBAR sesuai dengan SPO dan formulir yang ditetapkan.

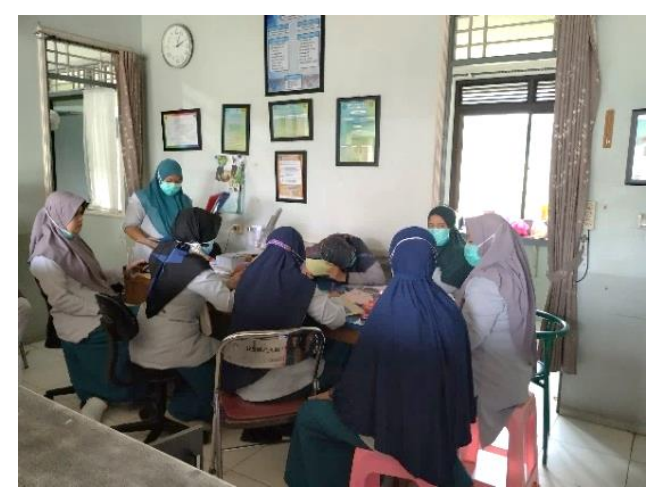

Gambar 5. Pelaksanaan Nursing Handover di Nurse Station Ruang Percontohan

Pada saat bedside handover di kamar pasien terlihat hanya dilakukan oleh beberapa perwakilan perawat antarshift dengan waktu yang sangat singkat, yaitu kurang dari 2 menit. Pengurangan durasi ke kamar pasien dilakukan untuk menyesuaikan dengan masa pandemi. Hal ini dikarenakan untuk meminimalkan waktu kontak dengan pasien dan keluarga di kamar rawat.

Bedside handover tetap dilakukan walaupun hanya sebentar dikarenakan adanya keluhan pasien yang menyampaikan bahwa merasa tidak dilayani apabila perawat jarang masuk ke kamar pasein. Sehingga bedside handover masa pandemi tetap dilaksanakan dengan waktu seminimal mungkin dengan tetap mentatati protokol kesehatan.

\section{f. Evaluasi}

Pertama, handover tetap dilakukan di nurse station oleh antarshift perawat. Handover di nurse station tetap dilakanakan dengan tetap mematuhi protokol kesehatan. Adapun alasan tidak memodifikasi handover secara daring karena memiliki kendala yaitu belum optimalnya sistem manjemen informasi di rumah sakit khususnya belum ada pendokumentasian asuhan keperawatan berbasis komputerisasi yang terintegrasi. Sehingga jika handover dilakukan secara daring maka proses validasi data untuk melihat dokumen medical record (paper based) akan mengalami kesulitan.

Bagi rumah sakit yang sudah optimal dalam penggunaan teknologi informasi, pelaksanaan handover dapat dilakukan dengan cara sebagian petugas perawatan dapat berada di ruang rapat atau di ruang kerja dengan tetap memperhatikan sosial distancing. Serah terima di samping bed pasien hanya didampingi oleh perawat yang berdinas saat itu, sementara yang lainnya berada di ruangan yang berbeda. Petugas yang telah menyelesaikan dinasnya menyerahkan pasien dengan menggunakan aplikasi Zoom. External mobile camera juga digunakan melihat lebih fokus alat-alat yang terpasang pada pasien. Perawat lain berada di ruang rapat mengikuti proses handover dengan melihat pada layar lebar yang dilengkapi speaker. Perawat lain yang tidak hadir dapat mengikuti handover melalui smartphone pribadi. (Wasserteil et al., 2020). 


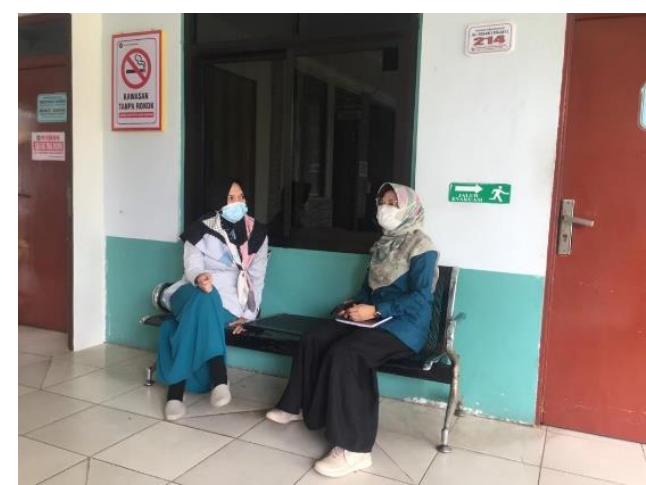

Gambar 6. Penyampaian Feedback dan Evaluasi Pelaksanaan Nursing Handover di Ruang Percontohan

Kedua, saat nursing handover menggunakan metode SBAR perawat masih belum maksimal menyampaikan masalah dan tindakan keperawatan mandiri. Hal ini tentunya menjadi bahan evaluasi dan masukan agar pada saat timbang terima menggunakan metode SBAR tidak hanya menyampaikan masalah medis dan tindakan kolaborasi.

Ketiga, bedside handover di kamar pasien tetap dilaksanakan walaupun dengan waktu kurang dari 2 menit. Hal ini dikarenakan pasien akan merasa tidak dilayani jika tidak ada perawat yang melakukan kunjungan saat pergantian shift. Pasien merasa tidak ada pemberitahuan jika ada perawat yang berganti dinas. Demi menjaga kepuasan pasien namun tetap meminimalkan waktu kontak dengan pasein, maka solusinya adalah dengan mempersingkat waktu bedside handover di kamar pasien.

Keempat, penggunaan formulir handover untuk tindakan sementara di luar ruang rawat inap (tindakan operasi, tindakan hemodialisa, tindakan pemeriksaan penunjang) sudah dilakukan. Pada awalnya untuk handover tindakan tersebut memiliki formulir. Sehingga memungkinkan terjadinya saling lempar tanggung jawab petugas jika tidak ada aspek legal etik saat tindakan sementara tersebut. Namun, saat ini perawat dan petugas kesehatan lainnya telah menerapkan handover untuk tindakan sementara.

\section{KESIMPULAN}

Bedside handover di kamar pasien saat pandemi dilakukan kurang dari 2 menit untuk tetap menjamin kepuasan pasien. Perawat di rumah sakit harus lebih meningkatkan komunikasi SBAR saat pergantian shif, khususnya penyempaian masalah keperawatan dan tindakan keperawatan mandiri. Peningkatan supervisi keperawatan diperlukan untuk menjamin pelaksanaan nursing handover sesuai dengan SPO yang ditetapkan. Selain itu, kedepannya rumah sakit sebaiknya mulai mengembangkan dokumentasi asuhan keperawatan digital yang terintegerasi, sehingga sistem manajemen informasi keperawatan dapat dioptimalkan. Penggunaan sistem informasi manajemen asuhan keperawatan juga akan memudahkan proses nursing handover. Hal ini guna menyikapi tantangan new normal yang sebagian besar kegiatan menggunakan metode daring. 


\section{DAFTAR PUSTAKA}

Al Thobaity, A. and Alshammari, F. (2020) 'Nurses on the Frontline against the COVID-19 Pandemic: An Integrative Review', Dubai Medical Journal, 3(3), pp. 87-92. doi: 10.1159/000509361.

Fatwa, A. (2020) 'Pemanfaatan Teknologi Pendidikan di Era New Normal', Indonesian Journal of Instructional Technology, 1(Agustus), pp. 20-30. Available https://journal.kurasinstitute.com/index.php/ijit/article/view/37.

Haswar, A. M. (2020). 'Satu Lagi Perawat di Kalsel Meninggal karena Infeksi Covid-19', Kompas.com, 18 November. Available at: https://regional.kompas.com/read/2020/11/18/22455671/satu-lagiperawat-di-kalsel-meninggal-karena-infeksi-covid-19.

Herawati, V. D. et al. (2018). 'the Effectiveness of Coaching Using Sbar (Situation, Background, Assessment, Recommendation) Communication Tool on Nursing Shift Handovers', Belitung Nursing Journal, 4(2), pp. 177185. doi: 10.33546/bnj.464.

Huang, L. et al. (2020). 'Special attention to nurses' protection during the COVID-19 epidemic', Critical Care. Critical Care, 24(1), pp. 10-12. doi: 10.1186/s13054-020-2841-7.

Loefgren Vretare, L. and Anderzén-Carlsson, A. (2020). 'The critical care nurse's perception of handover: A phenomenographic study', Intensive and Critical Care Nursing. The Author(s), 58, p. 102807. doi: 10.1016/j.iccn.2020.102807.

Nursalam. (2015). Manajemen Keperawatan Aplikasi dalam Praktik Keperawatan Profesional, Salemba Medika. Jakarta: Salemba Medika. doi: $10.1001 /$ archinte.165.22.2659.

Oxyandi, M. and Endayni, N. (2020). 'Pengaruh Metode Komunikasi Efektif Sbar Terhadap Pelaksanaan Timbang Terima', Jurnal 'Aisyiyah Medika, 5(1), pp. 162-172. doi: 10.36729/jam.v5i1.322.

Rifai, A., Afandi, A. T. and Hasanah, A. (2020). 'Bedside Nursing Handover: Patient's Perspective', Nurseline Journal, 4(2), p. 123. doi: 10.19184/nlj.v4i2.15422.

Standar Nasional Akreditasi Rumah Sakit Edisi 1.1 (2019). Jakarta: Sakit, Komite Akreditasi Rumah.

Utama, T. A., Sukmawati and Dianty, F. E. (2020). 'Pengalaman Perawat Dalam Memberikan Asuhan Keperawatan Pada Pasien Terinfeksi Covid19', Jurnal IImu Keperawatan Indonesia (JIKPI), 1(2), pp. 13-19. Available at: http://jurnal.umitra.ac.id/index.php/jikpi/article/view/478.

Wasserteil, N. et al. (2020). 'Handover of patients: the challenges of COVID19', Journal of Perinatology. Springer US, 40(10), pp. 1453-1454. doi: 10.1038/s41372-020-00792-y. 